Madhok, S. (2018) Coloniality, Political Subjectivation and the Gendered Politics of Protest in a 'State of Exception' in Feminist Review, 119 ( in Press).

\title{
Coloniality, Political Subjectivation and the Gendered Politics of Protest in a 'State of Exception'
}

\begin{abstract}
:
In this paper, I shall make the following propositions: In order to conceptually capture and represent acts of political protest in a state of exception, we will need to reorient and supplement our representational apparatuses and also our theoretical frameworks for thinking about the gendered modes of protest under emergency laws and political abandonment. Through an analysis of the 'naked protest' of the Meira Peibis in Manipur, a 'state of exception' in democratic India, I shall argue for a series of supplementations to our current thinking on intersectionality, bare life and political subjectivation, if we are to make sense of political acts of resistance, refusal and disavowal of the law of exception.
\end{abstract}

In the summer of 2014, I met the Meira Peibis in Imphal. In Meitei, the phrase translates as the 'torch bearers' or 'carriers of the flame', and the Meira Peibis have been doing exactly that: holding the flame at the setting of dusk and holding forth their presence till the first morning light filters through neighborhoods across Manipur. In some ways, the Meira Peibis are a version of neighbourhood watch. They are mostly older and in the majority of cases, married women who operate as neighbourhood witnessing/documenting group, recording the disappearance of young people, mostly boys and men from their neighbourhoods and localities, made to disappear or extrajudicially 'eliminated' (Hegde Commission 2013:85) in 'fake encounters' through 'excessive' [force] or 'retaliatory force' deployed by the military and the paramilitary forces, ${ }^{1}$. And, armed with their documents comprising names, addresses and time of 'pick up/abduction' of the night before, the Meira Peibis make their way the next morning to the local police station and sometimes to the military headquarters to present their evidence of abduction/disappeared young men, and to demand their release. This list keeping assumes significance because in the six

\footnotetext{
${ }^{1}$ Supreme Court of India (2016). Writ Petition ( Criminal) No. 129 of 2012. Pg 82. Henceforth referred to as Supreme Court (2016).
} 
decades long counter insurgency operations in the state, which have seen the deployment of emergency laws instituting the right to kill by the security forces and the de facto suspension of fundamental citizen guarantees including 'habeas corpus, ${ }^{2}$ and the constitutionally protected rights to life (Article 21) and recourse to law. The Meira Peibis have become important information keepers of all those 'picked up' for interrogation, tortured and left to die, and of all those who have simply 'disappeared'. Under the emergency laws operating in Manipur, the security authorities have accorded themselves an exception from providing any information on those in custody.

Since 1958, Manipur, a state in India’s North East, is a designated 'disturbed area' and a 'state of exception' established under exceptional law. In light of the predominant understandings of 'state of exception' within contemporary political theory $^{3}$, which operates through banishing any strain of political life, one must qualify the somewhat anomalous nature ${ }^{4}$ of the 'state of exception' in operation in the state. Manipur, a sovereign princely state, acceded to independent India in 1949, whence upon it has been administered through directly elected representatives to its legislative assembly and also sends representatives to India's Parliament. There is however a caveat: since 1958, the people of Manipur through their representatives are not sovereign; it is the law of exception that rules sovereign and governs life and death in the state. The exceptional law designating Manipur as a 'disturbed area', known as the 'Armed Forces Special Powers Act' (AFSPA), came into force on 11 September 1958, even though the emergency provisions are borrowed from an older colonial law (Kikon 2009) promulgated in 1942 to 'suppress' the Indian nationalist movement (Akoijam 2005:484). The AFSPA confers ‘special powers' on armed forces personnel including the right to kill with legal impunity. Under the terms of the AFSPA, any commissioned, or non- commissioned officer or any other person of 'equivalent rank in the armed forces may':

\footnotetext{
${ }^{2}$ In theory, habeas corpus exists but in practice it is hardly ever upheld or invoked. According to Babloo Loitongbam, the founder and executive director of Human Rights Alert, and also a petitioner to the Supreme Court in the Writ Petition (Criminal) No. 129 of 2012, in effect, this means that "in almost all cases, even after a finding by the high court of enforced disappearance and extra judicial execution, no FIR (First Information Report) is registered by the authorities against the perpetrators” (personal communication, 11 October 2017).

${ }^{3}$ In particular, I am referring to Giorgio Agamben 'Homo Sacer': Sovereign Power and Bare Life

${ }^{4}$ Bora ( 2010:342) refers to the 'paradoxical' state of affairs in Manipur where counter insurgency operations coexist alongside 'democratic institutions'.
} 
(a) Fire upon or use other kinds of force even if it causes death;

(b) Arrest without warrant, any person who has committed a cognizable offence or against whom a reasonable suspicion exists that he has committed or is about to commit a cognizable offence and may sue such force as may be necessary to effect the arrest.

(c) Enter and search without warrant any premise to make any such arrest as aforesaid

(d) No prosecution, suit or other legal proceedings shall be instituted, except with the previous sanction of the Central government, against any person in respect of anything done or purported to be done in exercise of the powers conferred by the Act Military has legal immunity

(e) Government's judgment on why an area is found to be disturbed is not subject to judicial review ${ }^{5}$.

The state of exception instituted through exceptional law has not been without judicial and parliamentary oversight ${ }^{6}$ or indeed international scrutiny ${ }^{7}$. The Supreme Court of India has upheld the constitutional validity of the AFSPA even while ruling to institute operational safeguards and 'prerequisite conditions'8 ${ }^{8}$ In its 2016 judgment, however, the court recognized the flagrant disregard of these conditions and safeguards, noting that, 'a particular situation of internal disturbance has prevailed for decades and the ordinary citizens of Manipur have had little access and recourse to law in the situation that they find themselves placed in' (Supreme Court 2016:24).

The operation of exceptional law has rendered Manipur a vast killing field. The 1958 Act has resulted in a 'plethora of acts' (Akoijam 2005:482) of state directed murderous killing, enforced disappearances, torture and abandonment of citizens in a

\footnotetext{
${ }^{5}$ Armed Forces Special Powers Act, 1958.

${ }^{6}$ See in particular, The Report of the J.S. Verma "Committee on Amendments to Criminal Law" Government of India. 23 January 2013; Report of Justice Jeevan Reddy Committee constituted to review the provisions contained in the Armed Forces Special Powers Act (AFSPA), Government of India, 2005.

7 UN Human Rights Committee (CCPR/C/79/Add. 81); Report of the working Group on Universal Human Rights Periodic Reviews 2012 and 2017. https://documents-ddsny.un.org/doc/UNDOC/GEN/G12/151/08/PDF/G1215108.pdf?OpenElement ; https://documents-dds ny.un.org/doc/UNDOC/GEN/G17/193/56/PDF/G1719356.pdf?OpenElement

8 See ‘Naga People’s Movement of Human Rights vs Union of India’ ( AIR 1998SC 431)
} 
representative democracy. In fact, Manipur can be considered a prototype of the contradiction inhering in the law of exception, which in its promulgation gets simultaneously signified as exceptional law: as an exceptional 'other' to existing law itself; as its non normative other. And, far from producing a politically devoid 'bare life' through law as exception, this aporia between law of exception and exceptional law in fact results in producing a politics of protest and demands for life amidst the legal denial of life itself. But how are we to theorise such an anomalous state of exception? In what follows, I shall argue for a series of supplementations to received frameworks for thinking about representation and modes of protest in states of exception. In particular, I shall make two sets of inter-related arguments: Firstly, in order to represent and conceptually capture the political protests in a state of exception, we will need to supplement our representational apparatuses, and in particular, supplement intersectionality with coloniality. And secondly, in order to provide the conceptual descriptions of political acts of subjectification of gendered subjects under emergency laws, we will need to introduce three sets of supplementations to existing theorising of 'bare life' on the one hand, and to those of political subjectivation on the other.

\section{The Vigil}

It was quite by coincidence that I arranged to meet the Meira Peibis. As is sometimes the case, the plan to meet them arose amidst unrelated, albeit, very engaged conversation with human rights activists in Imphal, the capital city of Manipur, where I was asked about my current work on vernacular rights cultures. As I began to talk about the Urdu/Arabic word haq, a literal term for a right that is used in many parts of North Africa, The Middle East and South Asia, which I have been tracking philosophically and also ethnographically documenting for a few years, I was stopped somewhat abruptly mid-flow and told, 'but the Meira Peibis use haq too'! Now in all my tracking of the term-from its pre-Islamic origins, classical Hebrew usage, to its Qur'anic form and its entry into Indian Subcontinent through Persian and its usage in Hindustani/Urdu (Madhok 2017), I had thus far not considered that the word would be in currency this far east. Encouraged by this conversation, and to cut the long story short, I went to meet the Meira Peibis, and at that point with the sole objective of trying to document how they deploy the term haq. 
In a non descript tin and wood shack by the side of the nodal road [Jawaharlal Nehru Medical Institute Road] to the east of Imphal, the capital city of Manipur, the Meira Peibis had set up a vigil on public land from where they have carried out their relay collective fast in solidarity with Chanu Irom Sharmila, Manipur's most famous peace activist, who in November 2000 embarked on an indefinite fast demanding the withdrawal of the AFSPA from the state. At the time of my meeting the Meira Peibis, Irom Sharmila's fast had reached its $14^{\text {th }}$ year, and in May 2014, Irom Sharmila's prison record clocked her as having spent 4,776 days in prison (Bhonsle 2014). Two years later, whenceupon on 15 August 2016, Irom Sharmila called off her fast, her act of self-denial has been registered as the longest ever act of an individual withholding food in recorded history. As has been extensively chronicled, Irom Sharmila embarked on her fast as a result of the specific events of November 2, 2000, when the para-military forces opened fire on people who had gathered to plan a peaceful protest against the AFSPA killing ten people including school children. Not unlike the case today, the state killing of civilians was no uncommon occurrence in Manipur; however, the brutality and dehumanisation on display moved Irom Sharmila to act in protest against the daily indignities, human rights violations and lack of civil liberties experienced by the Manipuris. Her indefinite fast came to the notice of the authorities and she was arrested on charges of 'attempted suicide' and imprisoned.

The authorities read Irom Sharmila's resistance against the exceptional law not as an act of resistance against the 'state of exception' and therefore, a claim to a restoration of the right to life and justice in the face of death under emergency and abandonment, but rather as an attempt of an individual to willfully commit suicide. Until December 2014, under Section 309 of Indian Penal Code, any attempt to commit suicide by individuals was deemed a crime inviting a mandatory prison sentence. In a scene saturated by irony, during the entire period of her fast, give or take a few days of exception, Irom Sharmila was held in custody for attempting suicide in breach of law of the land and chained to her prison bed in a security ward in a hospital at the Jawaharlal Nehru Hospital in Imphal. She refused bail and her refusal of food resulted in her being force-fed through her nose by the authorities. In line with the abandonment of subjects under emergency laws, it is not surprising that till 2009, about nine years into her fast, no senior national level leader of any political party met 
with her to discuss her demand ${ }^{9}$. This judicial abandonment of Irom Sharmila together with the lack of any concerted or urgent political response or even concern by the state authorities to her extraordinary protest must be read in light of prevailing coloniality of knowledge production, both colonial and postcolonial, which has racialised the people of the Manipur and those belonging to the North Eastern States of India, as 'racially mongolian', belonging to 'another civilization', the culturally 'other' (Bora 2010:347), and thereby, outside of culturally normative forms of representation constituting 'Indianness' and Indian citizenship.

On the day I met the Meira Peibis, there were only two of them in charge of the vigil in their makeshift shack. The shack itself had been divided into two separate spaces: one for public conversations, discussions and interviews with the media, and the other, contained a bed, a small makeshift kitchen and a small television. There was also a small opening that led out into a bathing area at the back. The Meira Peibis told me that they had been on a relay fast in solidarity with Irom Sharmila since 2004, which meant that on any given day, at least one Meira Peibi was on a fast alongside Irom Sharmila and in protest against the AFSPA. The Meira Peibis, however, had not always been list keepers of the disappeared and those abducted by the state, their originary and earlier avatar was in the mould of a rather conventional neighbourhood group of mothers, who met to discuss and devise collective strategies for tackling social issues, particularly of drug addiction and alcoholism amongst the neighbourhood youth. But one event led to their decision to align themselves with Irom Sharmila's struggle. On 11 July 2004, Thangjam Manorama a 24-year-old woman was abducted from her home by military personnel but not before subjecting her to grievous beating and torture within the precincts of her home and witnessed by her mother and younger brothers. Later that day, her brutalised bullet ridden body replete with semen and other bodily fluids intact on her clothes were found - there were also bullets found in her vagina. The Meira Peibis, overcome by despair, grief, hopelessness and anger at the news of the murder, gang rape, and 'brutal merciless torture $^{, 10}$ of Manorama, by the military staged a 'naked protest' outside the Kangla

\footnotetext{
${ }^{9}$ Compare this with the hunger strike of the prominent anti corruption activist Anna Hazare, which evinced a response by the government within 87 hours https://scroll.in/article/804983/why-iromsharmilas-fast-holds-no-meaning-for-those-shes-trying-to-move

${ }^{10}$ Report of the Commission of the Judicial Inquiry ( Manorama Death Inquiry Commission), 2004.

The report was hidden from public view for nearly10 years only becoming public when it was
} 
Fort, a symbol of Manipur's sovereignty and the seat of Manipur's ruler kings prior to its accession into postcolonial India in 1949, holding a banner that ran across their bodies which read: 'Indian Army Rape Us'. The naked protest by these mostly middle aged, married and 'respectable' women issuing an open call to the military to rape them draws attention to the corporeal nature of coloniality and colonial occupation but also to the body as the site of political protest in the face of exceptional law. In this paper, I wish to draw attention to the significance of the naked protest as an act of political subjectivation and together with Irom Sharmila's 16 year long fast, consider what these acts which turn the self into a site of political protest, mean for rights, law and gendered bodies in states of exception.

\section{Intersectionality and Coloniality}

The naked protest by the Meria Peibis raises several theoretical and conceptual questions. Crucial amongst these is one of representation and more precisely, that of feminist representation in contexts of counter insurgency and state violence. The complexity of oppressions and identities alongside a recognition of one's complicity in reproducing existing epistemic hierarchies has led feminist scholars to insist on intersectional analyses in order to produce theoretical, empirical and analytical scholarship at the intersections of hierarchy and oppressions. As is well known, Kimberle Crenshaw coined the term intersectionality, even though the concept of complex and intersecting identities had been doing its rounds in black and Chicana feminist circles for a considerable time (Collins and Bilge 2016). Crenshaw (1989) in her writing on black women's effacement from the legal system in the United States highlights the legal erasure of black women resulting from the inability of law to deal with black women's experience, reading black for males and women for white women. Following Crenshaw's legal analysis, the complex triadic intersection of race, gender and class as defining experience of subordination and also of identities has acquired an epistemic and methodological significance with intersectionality characterised as an 'analytic of power'"11, and the most significant conceptual category in the social sciences of the past quarter century (McCall 2005). While

submitted to to the Supreme Court in 2014. http://www.thehindu.com/news/national/manorama-deathbrutal-torture-probe-panel/article6596278.ece

${ }^{11}$ See Cho et al ( 2013) Special Issue on 'Intersectionality; Signs. 
intersectionality has attracted its fair share of criticism, especially its deployment of identity categories (Brown (2005), Puar (2012), in recent years, however, scholars have expressed apprehensions over attempts at 'whitening' the genealogy of intersectionality in order to accommodate the concerns and trajectories of white feminism ${ }^{12}$. What is particularly worrying in these 'whitening' efforts is the increasing displacement of race and the experience of racism in intersectionality accounts (Lewis 2013, Henry 2017), as though somehow, using the term intersectionality means that one is not required to name race any longer. This refusal to name or acknowledge race preferring to substitute it with 'intersectionality', performs particular epistemic and phenomenological work and in particular, it serves to minimise epistemic/embodied discomfort of acknowledging one's implication in the structural relations and practices that produce racialised bodies and knowledges.

The context of the naked protest of the Meira Peibis in the existing state of exception in Manipur, generates yet another dilemma for intersectional accounts but this time engendered by the nature of the political context and the quality of gendered citizenship it installs, and it is this: can existing multi-axial categories of oppression used in intersectional accounts adequately represent racialised gendered bodies in a state of exception? And, furthermore, in the context of the counterinsurgency operations by the Indian state in Manipur, how do standard intersectional accounts fare in terms of their conceptual adequacy and capacity for complexity, where complexity, in this case, includes the disavowal of the nation state and its colonial occupation. How to represent marginalised groups officially outside of legal representation in terms to their access to life and liberty but included through representation in politics? In other words, how to include groups that are included as part of formal politics but excluded from the democratic processes associated with political citizenship? The operation of a formal political process in Manipur through organising periodic elections in which citizens exercise their political right to vote has enabled the Indian state to maintain both the veneer of democracy while also imposing a state of exception that denies all other political rights. In this context, can nation based feminist movements represent gendered protests that disavow the nationstate? In my conversations with the Meira Peibis, the sense of alienation from what

\footnotetext{
${ }^{12}$ See Patricia Hill Collins and Sirma Bilge ( 2019) and also Sumi Cho et al ( 2013).
} 
was seen as the hegemonic “Indian feminist struggle' was very palpable and made very clear. It is worth asking for instance, why is it the case that the brutal rape and murder of Thangjam Manorama in Manipur by the Indian security forces not lead to the spilling of bodies in metropolitan India? Why did not the sixteen-year hunger strike of Irom Sharmila not emerge as the central question raised by India's feminist movement? What kinds of intersectional identities and violence is the Indian feminist movement able to represent? What forms of epistemic and representational authority does it mobilise? While these questions are undoubtedly numerous, they point towards the need for a supplementation to our accounts of intersectionality. In other words, the naked protest by the Meira Peibis together with Irom Sharmila's 16 year fast require supplementing existing axes of intersectional experience with that of coloniality. I am here drawing on the work of coloniality theorists ${ }^{13}$, and in particular on Maria Lugones' important intervention for intersectionality to acknowledge 'coloniality of gender' or the racialised, capitalist gender oppression- and 'colonial difference' as a starting point for feminist coalitional thinking and politics $(2007 ; 2010)$. However, my argument is quite separate from that of Lugones, not least because 'coloniality of gender' rests on the premise that the gender is a colonial imposition imposed by the European colonisers ${ }^{14}$ but also in asking that coloniality be recognized as a category of intersectional analyses, I am requiring that we introduce further complexity in our intersectional accounts. In other words, by arguing for supplementing intersectionality with coloniality, I am asking for integrating contemporary contexts of occupation, emergency, wilful unknowing/ignorance, abandonment and political oppression in our deployments of intersectionality so as to show not only how experiences of gender, sexuality, race and caste are produced within contemporary relations of hierarchy, oppression, coloniality and settler colonialisms but also how political spaces and practices are regulated, circumscribed and produced through these. More specifically, by deploying coloniality in this paper, I wish to draw attention to the policies and practices of the Indian state, which enable it to extend formations of colonial power such as the imposition of the AFSPA and thereby institutionalise a differential

\footnotetext{
${ }^{13}$ In particular, I am referring to the scholarship of Anibal Quijano ( 2000), A. Escobar ( 2007), W. Mignolo( 2012) and Maria Lugones ( 2007; 2010).

${ }^{14}$ For a very helpful discussion and critique of coloniality theorists including Maria Lugones see Mendoza (2016).
} 
distribution of citizenship characterised by judicial and political abandonment including wilful ignorance of legal safeguards and instituted due process, legitmised through racialised difference. In Manipur, coloniality co-exists alongside electoral representation and frames legal citizenship while reproducing itself through both. To put another way, legal attempts to regulate the operation of emergency laws via insertion of legal 'safeguards' result in safeguarding exception and reentrenching coloniality by yielding a willful institutional ignorance of these safeguards and producing an effect of there being no recourse to and/or of being removed from the protection of law.

Producing intersectional accounts of oppression through the vector of coloniality and occupation will foreground the manner in which coloniality disrupts attempts at stabilising meanings and/or practices of gender, caste, sexuality, class and race through a nation centric imaginary. For instance, the military rape of Thangjam manorama and the naked protests of the Meira Peibis dispute any notion that the nation state is a protector of women, or that the caste and class identities of these women, mostly middle and upper castes, guaranteed them the minimal recognition and even caste based respect that women outside of Manipur and the 'disturbed areas' nominally expect to receive from state authorities. While the sexual torture, rape and murderous killing of Thangjam Manorama brought into public view the racialised, colonised and sexualised bodies of women in Manipur as available for sexual exploitation, violence and state torture (Bora 2010, Osuri 2015), their differentiated treatment as gendered subjects in a state of exception not only removed them from any protections against sexual torture perpetrated by the state under emergency laws but also the non recognition of sexual torture under these laws meant that sexual torture was itself invisibilised through law.

\section{Gender, Bare life and Political Subjectivation}

But even if we become reflexive in relation to our own feminist frames of representation and even adopt coloniality as an axis of oppression within intersectional accounts, a prior question still remains: how to represent the modalities of protest taken up by gendered bodies in states of exception? The protests 
themselves, that of the sixteen year long fast/hunger strike by Irom Sharmila and the relayed hunger strike by the Meira Peibis as well as their naked protest activates not only a theoretical paradox for us to consider but also a put forward a conceptual challenge: how to reconcile sovereignty as bare life in states of exception alongside the proliferation of protesting bodies in these exceptional zones? Or put in another way: how do we think of bare life-that is life which is made political through the exercise of sovereign power as exception- as the site of emancipatory politics? How do we think of subjects who under emergency and abandonment make the right to life as the foremost question of politics? As you will recall, bare life for Agamben (1998) is one stripped of political significance and exposed through murderous violence. Following from this view of life made bare and absolved of any political significance through biopolitical operation of sovereign power, the questions to consider here then are the following: what are the modalities and practices of protest under conditions of exception? What forms of subjectivation and what vocabularies of protest are deployed in order to register refusal of the state of exception? What of the biopolitical body/subject under exception? And finally, does the gendered body make any difference to registering the disavowal of bare life and the state of exception?

Agamben's own answer to the possibilities of political subjectivation in states of exception has been of course, in the negative. And, it is this 'radical suspension of politics' that lies at the heart of Jacques Rancierre's critique of Agamben. In 'who is the subject of the rights of man, Rancierre $(2004,2010)$ takes both Hannah Arendt (1951) and Giorgio Agamben (1998) to task for their negative reading of the paradox of the founding moment of republicanism: i.e. the interval between man and citizen in the declaration of the rights of man and citizen, which he argues, is a depolitcising move that confines the subject of rights to an already determined and 'designate collections of individuals' who are either already citizens and already enjoy rights by virtue of having the 'right to have rights' (Arendt 1951) or those who are not and therefore, who only have the rights of man, which in effect amounts to having no rights at all. In contrast, Rancierre argues that the 'subject of rights is the subject- or more accurately the process of subjectivation - that bridges the interval between the two forms of existence of those rights' (2004:302) and therefore, the interval between rights of man and citizen, neither signifies a 'theoretical lock', a 'void' or an 'abyss' but instead the possibility of political subjectivation and of democratic politics as 
dissensus. 'The question of the 'political subject', writes Rancierre, 'is not caught between the void term of man and the plenitude of the citizen with its actual rights. A political subject is a capacity for staging scenes of dissensus... a dispute over what is given and about the frame within which we see something as given...the putting of two worlds in one and the same world' (2010:69). Consequently, Rancierre proposes that the question of the rights of man be reset as: "the rights of man are the rights of those who have not the rights that they have and have the rights that they have not" (2004:302). Central to this recasting is the recognition and the necessity of producing accounts of the political subjectivation and collective action of those 'who have no part' (2004:305), and who are represented as beyond accounts of democracy or anti democracy, justice or injustice.

Political subjectivation as theorised by Rancierre provides a crucial building block for thinking about the political protest of the Meira Peibis and of Irom Sharmila. However, just as in the case supplementation of intersectionality discussed above, in order to think about political subjectivation of gendered bodies in states of exception, it too will require three different kinds of supplementation. The supplementation becomes crucial because neither Agamben nor Rancierre work with intersectional bodies and personhood or with a carefully calibrated account of the fields of power in which makes political subjectivation becomes possible. On the contrary, both work with binary accounts of power: in the case of Agamben, overwhelming power leaves no room for political subjectivation, marking all bodies irrespective of their differentiated positionings; and Rancierre, too gives little account of specific contexts of power (McNay 2014) within political subjectivation occurs and next to none of the specific forms it might take for differently gendered bodies. In other words, while Agamben's version of 'bare life' and 'states of exception' capture the legal abandonment of populations and their juridical exclusion from the legal domain of political rights, but this is at best a generic account and one disrupted all too easily by gendered corporeality, which draws attention to the inherent differentiation of bodies in states of exception and the differential disbursement of torture, particularly sexual torture of differently gendered bodies. In other words, the gendered body requires a different account of the state of exception. 
Therefore, while the regular spilling of gendered bodies on Manipur's streets tells us that it is not enough to only focus on the legally sanctioned juridical legal excesses, even if thinking in terms of 'bare life' does give us a very effective phrase to capture both the sovereignty of power and its exclusionary impulse-of inclusion/exclusion via law - and that we also must focus on political subjectivation and of the ways in which this inclusion/exclusion or the politics of life as bare life is disavowed/refused. This political subjectification, however, cannot be thought outside of specific contexts of power and must not only focus on the modalities and sites of protest but also on the imaginaries, vocabularies and strategies of resistance, collective action, refusals and disavowals that are performed in a state of exception. The three kinds of supplementation I am referring to enables an optic into the forms of political subjectivation undertaken by gendered bodies in a state of exception and are the following: to drag 'bare life' and 'state and exception' outside its standard historical and political context of theorising, i.e. in the context of the two wars in Europe and their aftermath and into 'most of the world', where state abandonment, emergency, democratic process and political subjectification/ disavowal occur on a 'continuum of simultaneity' (Madhok, Phillips and Wilson 2013); to provide gendered accounts of the politics of life and the forms of counter biopolitics (Comaroff 2007) it generates; and finally, an attention to the processes and vocabularies of subjectivation that accompanies public acts of disavowal of the state/state of exception. In sum, the supplementation of accounts of political subjectivation to account for gendered bodies in states of exception enables us to recognise that gendered subjects under laws of exception are not only juridical but also corporeal, and, that they are not only discursive but also performative. Gendered subjects in states of exception are juridical because of their explicit turn to constitutional legalism/ rights even when it's explicit that they are abandoned by the law and by the guarantees of human rights under law. On the other hand, the gendered subject is performative because they occupy public space and, in line with Rancierre, perform the rights they don't have and in so doing, lay a claim on the rights that they don't. More recently, Judith Butler ( 2015) raises the question of the performative politics of bodies in public assembly and she writes:

"When bodies assemble on the street, in the square, or in other forms of public space they are exercising a performative right to appear...showing up, standing, breathing, moving, standing still, speech and silence are all aspects of a sudden 
assembly...that puts livable life at the forefront of politics... where the legitimacy of the state is brought into question precisely by that way of appearing in public, the body itself exercises a right that is no right; in other words, it exercises a right that is being actively contested and destroyed by military force, and that, in its resistance to force, articulates its way of living, showing both its precarity and its right to persist... it is, in fact, the right to have rights, not as natural law or metaphysical stipulation, but as the persistence of the body, against those forces that seek its debilitation or eradication ... ( 2015:83)

While questions remain in Butler's account in relation to which bodies can occupy public spaces and of what might be the risks of appearing in public as well as the nature of claims allowable in these public spaces, however, performing the 'right to appear' as a collective in public does effectively draw attention to the absence of actually existing freedom and justice while also underscoring the possibilities of freedom yet to be in place. The Meira Peibis staged their naked protest and also their relay fast in a public space and in so doing announced their right to appear in the public through a double disavowal: In offering themselves to be raped by Indian army soldiers, the Meira Peibis drew attention to the gendered body as the site sovereign violence, sexual torture and colonial occupation, while simultaneously performing a claim that it be not thus, and thereby in so doing, exceed and go beyond the terms of justice/injustice described under the law. In other words, the claim that it be not thus, is premised on the human right not to be tortured recognized under international law but non-existent within Indian legal constitutionalism: India is not a signatory to the international covenant on torture and there are no domestic laws granting protection against state torture, which had they been would have been inadmissible owing to the operation of emergency laws in the 'state of exception'. Nonetheless, the public exhibition of the body as the site of sexual torture through offering up the body for sexual torture while staking a claim and a right to not be tortured disrupts the normative constitution of the public space. This public assembly of gendered bodies united by torture who in staking a claim against coloniality, corporeal occupation and sexual torture reconstitute the public space as one of rights - justice talk even if the this talk of justice and rights has been legally and experientially excluded from public access and view. 


\section{The emergence of a Juridical subject as a form of counter conduct}

Anyone who has paid even scant attention to the politics of protest in Manipur would have noticed the fluent and powerful deployment of the language of rights—both linked to the Indian constitution and to fundamental rights in particular and to International human rights discourse. So in short what is evident here is the emergence of a juridical subject who through finely honed legal subjectivities contests the operational of exceptional law, using legal frameworks to unmask the exceptional legal domain of rightlessness. Furthermore, and in line with Foucault's later work on ethics, the emergence of the juridical claim making from a position outside of law can also be viewed as a form of counter conduct, or what Ben Golder (2015) has termed a 'critical counter conduct of rights'. In other words, by authorising its own exception, law sets off a form of 'counter conduct', of 'wanting to be governed differently' (Foucault 2004:194) and for the restoration of rights removed by exceptional law. Now legal activists in Manipur have drawn attention to the aporias inherent between the law of exception and exceptional law by appeals to Indian legal constitutionalism and have demonstrated AFSPA's exceptional status compared to the operation of law in the rest of the country and also to the statutes prescribed under International human rights law. In 2012, two human rights groups brought a lawsuit on behalf of the victims of extra judicial executions to the Indian Supreme Court against the AFSPA and the Indian state's policy of extra judicial killings in Manipur. ${ }^{15}$ The petitioners in their submission to the court alleged that in the period 1979 to May 12, 2012, there had been 1,528 cases of extra judicial killings in 'fake encounters' 16 led by the military and the state police in Manipur ${ }^{17}$. Taking cognizance of the petition, the Supreme Court appointed a three member commission headed by former Supreme Court Justice Santosh Hegde to investigate and submit within 12 weeks, a 'through inquiry' on the first six cases detailed in the writ petition and record a 'finding regarding the past antecedents of the of victims and the circumstances in which they

\footnotetext{
${ }^{15}$ Extra Judicial Execution Victims Families Association ( EEVFAM) and Anr. Vs Union of India. Writ Petition ( Criminal) No. 129 of 2012.

${ }^{16}$ The term 'encounter' is an euphemism for murder in cold blood by the military and paramilitary forces under the protection of the AFSPA or indeed in state sponsored killing.

${ }^{17}$ It is important to note here that the writ petition explicitly deployed international human rights law such as the Minnesota Protocol on the Investigation of Potentially Unlawful Death also drew on the InterAmerican Court for Human Rights and the European Court for Human Rights for specific case law ( Babloo Loitongbam, personal communication 01 October 2017).
} 
were killed'. Subsequently, the Hegde Commission in its report dated 30 March 2013, concluded that that actions of the police and security forces had 'transgressed legal grounds' and furthermore, that in none of the six cases, did they deceased have any 'criminal antecedents'. In light of the Hegde findings on the Writ petition of EEVFAM, the Supreme Court issued an interim 85-page judgment in 2016, ruling that:

'...Excessive force or retaliatory force by the Manipur Police or the armed forces of the Union is not permissible... In cases such as the present, there is a greater duty of care and an equally greater necessity of a thorough enquiry since, we must not forget, the alleged 'enemy' in this case is a citizen of our country entitled to all fundamental rights including under Article 21 of the Constitution; our armed forces are not trained to fight and kill our own countrymen and women. To this we may add that ordinarily our armed forces should not be used against our countrymen and women'. (2016:66)

The juridical subject in the state of exception witnessed a legal victory through exploiting the aporias of law as exception/exceptional law. However, even while these aporias in law can be productively exploited to show the illegality of law of exception, it is important to not lose focus of the violations and forms of power directed at the gendered bodies under exceptional law. So for instance, the gendered violations lead us to ask, what forms of violations can be allowed on bodies abandoned to the status of the living dead? Does the sovereign right to kill also include particular forms of gendered violations such as militarised rape as was the case in Thangjam Manorama? How does the Supreme Court's enlightened judgment in the case of extra judicial killings cited above deal with the problem of differentiation ${ }^{18}$ of raced and gendered bodies and the intersectional experience of colonial occupation and gendered nature of sovereign violence and sexual violence? It is important to note that the Supreme Court judgment does not include any mention of sexual torture or mention gender differentiated bodies in its 85-page ruling ${ }^{19}$. The absence of 'negative differentiation' within law implies two things: that the citizen subject whom the judgment of the Supreme Court wishes to protect against the law of

\footnotetext{
${ }^{18}$ I borrow the term 'negative differentiation' from EP Ziarek ( 2008)

${ }^{19}$ As a matter of fact, neither did the EEVFAM lausuit. There were 24 women among the 1528 killed extra judicially but none were both murdered and raped as in the case of Manorama ( Babloo Loitongbam, personal communication, September 2017).
} 
exception is essentially the male citizen. And secondly, the silence of the law on gendered bodies means that sexual forms of torture are invisibilised under law. This intricate weaving of sexual torture in the deployment of the law of exception while also invisibilising its modes of operation within law is what is rendered visible by the naked protest of the Meira Peibis.

But while the production of the juridical subject and the aporias and fuzziness of law can be used to undermine the legal case for the state of exception and produce a case for 'counter biopolitics' (Comaroff), but it still however, doesn't explain the mode of the naked protest and indeed of the other forms of bodily protests resorted to by gendered bodies. In short, why does the corporeal assume centrality as a site of protest in the state of exception? In my view, the corporeal becomes significant because it is turned into a site of justice/injustice and thereby, another means for life. The hunger strike of Irom Sharmila and the naked protest by the Meira Peibis therefore, might also be read as the opening up not only another modality of protest but also inaugurating another means to life and justice. By centering the body - also the site of sovereign biopolitical power- as the key site of protest, the body is turned into a 'substitute layer for political protest' (Ziarek 2008) to both mimic but also to disrupt and deny sovereign power. Recently Banu Bargu (2016:33) and Jinee Lokaneeta (2017) have written on the body as a site of political protest. Writing in relation to the self immolation of the 26 year old Tunisian fruit seller Mohamed Bouazizi, Bargu writes, 'because the body has become the material site of war for which lives are weapons; the body can be seen as the congealment of an existential statement that refuses this reduction to biology...it might be that the very destruction of the body is the weapon to assert the claim that that a life without justice is not worth living’. In partial agreement with Bargu's position, I would however, argue that the turn to the corporeal is not only to annihilate the body in the face of injustice as is the case with Bouzazi, but in fact, to draw attention to the living body not only as the site of injustice but also as the possibility of justice itself. Here, Jinee Lokaneeta's critique of 'totalising violence in respect of Irom Sharmila's 16 year fast is helpful. In contrast to the 'necroresistance' offered in Bargu's account, Lokaneeta (2017) argues that in both carrying out her fast and also in choosing when to break it, Irom Sharmila exercised her power over both life and death, and thereby, deprived the state of its power over both. 
The centering of the corporeal under exceptional law/law as exception, signifies the body as the site of injustice/justice while also signaling a space not wholly determined by the oppresssor/oppressed discourse and violence, even as it shows up the body as one marked by coloniality, torture and abandonment. In refusing discourse of abandonment of the occupier, the corporeal opens up not only a site of politics but also the deployment of a particular vocabulary of protest. And, in the case of the Meira Peibis that vocabulary is one of the Urdu/Arabic term, haq. The vocabulary of haq is interesting because although it can be linked to the formal legal regime of rights, it has a particularly political imaginary, which is not derived from the state alone but exists independently even if relationally to the latter (Madhok 2017). The reference to haq, therefore, is to an entity, which exists independent of the law and possibly has a moral authority of its own. Possibly that is one reason why it is deployed by the Meira Peibis so forcefully against the legally sanctioned state of exception. And together with their corporeality, haq enables the Meira Peibis to register their epistemic presence.

To conclude, what I have been suggesting here is that in order to conceptually read the naked protest of the Meira Peibis (indeed even Irom Sharmila's unbroken fast) we need more complex and refined sets of conceptual lenses. The refinements and complexity I have suggested are in the nature of a series of supplementations: supplementing intersectionality with coloniality; bare life and state of exception with gender differentiated accounts and finally, conceptualizing political subjectivation in a state of exception as juridical but also corporeal, discursive and performative.

\section{Postscript}

Events have taken a significant turn since I wrote this piece for the Workshop on 'Justice/Injustice in South Asia' in February 2015 that have a bearing on the modes of protest that I have been referring to in this article. While more time is needed to undertake a careful theoretical analysis on the significance of the events, here are some of its important features. On August 15 2016, Irom Sharmila announced her decision to end her fast in the fast. Her struggle against the AFSPA was not working, she said, and that it was time to find another mode of struggle. Irom Sharmila, the symbol of Manipur's resistance against the AFSPA chose another symbolic date, of 
India's independence from British Rule to make this announcement. In her announcement to the gathered press, she said 'I have to change my strategy. Some people are seeing me as a strange woman because I want to join politics. They say politics is dirty, but so is society. I want to stand in the elections against the government" ${ }^{20}$. Her choice of the date to renounce her fast-15 August 2017- is not without significance: it sent a reminder to the nation that there were parts of the country that were still struggling for independence and were under occupation of colonial era laws. And, at the same time, it challenged the Indian state to a contest on its own terms, i.e. on the terrain of electoral democracy, thereby insisting that the struggle against AFSPA far from being over has begun anew and this time mobilising state laws and practices towards repealing the AFSPA. Upon renouncing her fast, Irom Sharmila was allowed to leave the hospital room, and she immersed herself in putting together political capital in order to contest the forthcoming state elections in March 2017. She set up a political party called the PRJA and announced that along with her party, she would be contesting elections to the state assembly. The people of Manipur went to vote for a new state assembly on March 2017. The PRJA and Irom Sharmila contested three assembly seats in all and lost all three, with Irom Sharmila polling only 90 votes in total. In an interview to the Indian Express on the day that election results were declared, Sharmila said 'I don’t feel that I am defeated morally. People would've have voted for me but their right to vote has been occupied by money. I will leave politics; I will never fight another election...I want PRJA to continue and to grow. I want it to become a peoples movement backed by the youth of Manipur"21.

Acknowledgements: My thanks to the editors and the two anonymous referees for their very helpful comments. And, very particular thanks to Babloo Loitongbam for crucial documents and answering my numerous queries.

\section{Bibliography}

\footnotetext{
${ }^{20}$ https://www.theguardian.com/world/2016/aug/09/indian-campaigner-irom-chanu-sharmila-end-16year-hunger-strike

${ }^{21}$ http://indianexpress.com/elections/manipur-assembly-elections-2017/manipur-elections-2017-theloneliness-that-is-irom-sharmila-4565096/
} 
Agamben, G. 1998. Homo Sacer: Sovereign power and bare life. Stanford University Press.

Akoijam, A.B., 2005. 'Act of Terror: The 'Embedded Disorder'of the AFSPA'. Sarai Media Collective, ed. Bare Acts: Sarai Reader, 5, pp.481-491.

Arendt, H., 1973. The Origins of Totalitarianism (Vol. 244). Houghton Mifflin Harcourt.

Armed Forces Special Powers Act 1958, Ministry of home Affairs, Government of India.http://mha.nic.in/sites/upload_files/mha/files/pdf/armed_forces_special_powers _act1958.pdf. Last accessed 12 March 2017.

Bargu, Banu. 2016. 'Why Did Bouazizi Burn Himself'? Constellations, Vo. 23, No.1 pp 27-36.

Bora, P. 2010. 'Between the Human, the Citizen and the Tribal: Reading Feminist Politics in India's Northeast' International Feminist Journal of Politics, 12(3-4), pp.341-360.

Cho, S. Crenshaw, K.W. and McCall, L., 2013. 'Toward a field of intersectionality studies: Theory, applications, and praxis'. Signs: Journal of Women in Culture and Society, 38(4), pp.785-810.

Collins, P.H. and Bilge, S., 2016. Intersectionality. John Wiley \& Sons.

Comaroff, J. 2007. 'Beyond bare life: AIDS,(bio) politics, and the neoliberal order’. Public culture, 19 (1), p.197.

Escobar A. 'Worlds and knowledges otherwise 1: The Latin American modernity/coloniality research program’. Cultural studies. 2007 Mar 1; 21(2-3): 179210.

Foucault. M. 2004. Security, Territory, and Population': Lectures at the College De France 1977-1988. Trans Graham Burchell. Palgrave MacMillan.

Golder, B. 2015. Foucault and the Politics of Rights. Stanford University Press.

Henry, M., 2017. 'Problematizing military masculinity, intersectionality and male vulnerability in feminist critical military studies’. Critical Military Studies, 3(2), pp.182-199. 
Kikon, D., 2009. 'The predicament of justice: fifty years of Armed Forces Special Powers Act in India.' Contemporary South Asia, 17(3), pp.271-282.

Lewis, G. 2013. 'Unsafe travel: Experiencing intersectionality and feminist displacements'. Signs: Journal of Women in Culture and Society, 38(4), pp.869-892.

Lokaneeta, J. 2017. 'Sovereignty, Violence and Resistance in North East India: Mapping Political Theory Today’ Theory \& Event, Volume 20, Number 1, January 2017, pp. 76-86

Lugones,M. 2007. 'Heterosexualism and the colonial/modern gender system’. Hypatia, 22(1), pp.186-219.

Lugones, M., 2010. ‘Toward a decolonial feminism'. Hypatia, 25(4), pp.742-759.

Madhok, S .2017. 'On Vernacular Rights Cultures and the Political Imaginaries of Haq', Humanity, 8.3 Winter.

McNay, L., 2014. The Misguided search for the political. John Wiley \& Sons.

Mignolo, W.D., 2012. Local histories/global designs: Coloniality, subaltern knowledges, and border thinking. Princeton University Press.

Osuri, G., 2015. 'Sovereignty, postcoloniality, and gendering human rights: rape and occupation’. borderlands ejournal, 14(1), pp.1-21.

Quijano, A., 2000. 'Coloniality of power and Eurocentrism in Latin America’. International Sociology, 15(2), pp.215-232.

Rancière, J., 2004. 'Who is the Subject of the Rights of Man'? The South Atlantic Quarterly, 103(2), pp.297-310.

Rancière, Jacques. ( 2010). 'Who is the Subject of the Rights of Man?.' Dissensus: on politics and aesthetics (2010): 62-75.

Report of the Commission of the Judicial Inquiry (Manorama Death Inquiry Commission), 2004.

Supreme Court of India Appointed Justice Santosh Hegde Commission' (2013). Also available at: https://humanrightsmanipur.files.wordpress.com/2013/07/ejevfam.pdf

Supreme Court of India Judgment in WRIT PETITION (CRIMINAL) NO.129 OF 2012 Extra Judicial Execution Victim Families Association (EEVFAM) \& Anr. 
Ziarek EP.2008. 'Bare life on strike: Notes on the biopolitics of race and gender'. South Atlantic Quarterly. 2008 Dec 21; 107(1): 89-105. 